\title{
Mining Conflict Resolution: A Case Study of Iron Sand Mining in Lumajang, Indonesia
}

\author{
I D Qurbani \\ Universitas Brawijaya, Malang \\ indah.qurbani80@ub.ac.id
}

\begin{abstract}
This research is a case study of iron sand mining conflict that occurred in Lumajang. Conflicts of interest and social will always arise in areas that have mining. Therefore, it is important to find conflict resolution which is in line with the locality of mining conflicts. Conversion of agricultural land into mining areas occurs so much that it harms farmers because agricultural land is decreasing. Environmental degradation is very fast. In spatial planning, Lumajang Regency was determined to be a disaster-prone area including floods and tsunamis. On the other hand, Lumajang Regency is also determined as a mining area, especially iron sand. This shows the overlapping of land use plans and spatial planning. Land conflicts must be very vulnerable. Conflict typology mapping is done by grouping them into conflict spaces.
\end{abstract}

Keywords: Conflict Resolution, Mining, Case Study.

\section{INTRODUCTION}

Lumajang Regency has a huge and abundant mining potential. However, in reality, the data and information are still very minimum. Therefore, it is necessary to cooperate with the private sector for further surveys and research. The mining potential in Lumajang Regency is found to be of limited variation but has enormous potential, the data and information include: location of revenues, number of reserves, and quality.[1]

There are a lot of sand and stone mining locations, including along the Rejali River, Regoyo River and Glidig River. Precisely located in the Candipuro, Pasirian, and Tempursari and Pronojiwo Districts, the area of mining sand and stone building materials 82.50 ha with a volume of $5,976,625 \mathrm{~m}^{3}$. The area of sand and stone is exploited 15 ha with a volume of 239,065 $\mathrm{m}^{3}$ or only $4 \%$ of the available capacity. Considering from the location of Lumajang Regency, it is quite close to several mountains namely Bromo, Tengger and Semeru, where around 60,000 hectares of land are volcanic sand mining with very good quality. In Lumajang, the metal materials containing sand is dominated by ferum $(\mathrm{Fe})$ which is around $40-50 \%$ and contains various impurities such as Titanium (Ti), Vanadium (V), Nickel (Ni), and Cobalt (Co). From these contents, Lumajang sand mining is widely used as a basic material for meeting various industrial needs, such as ferrous metals, cement industries, dry ink (toner) as a basis for copiers and laser inks, the main ingredients for cassette tapes, dyes and filter mixtures for paint and become the basic material of the permanent magnet industry.[2]

Environmental damage to the coastal area occurs along Lumajang, which is spread across eight sub-districts, there is excessive exploitation of beach sand using excavators. Sand from the southern coast of Lumajang is used to supply building needs throughout East Java Province. Regional characteristics of Lumajang Regency are fertile agricultural areas. However, there has 
been an overhaul of land use based on the number of mining business permits granted by the government. Conversion of agricultural land into mining areas occur, so it harms farmers, because agricultural land is decreasing, and environmental degradation is very fast.

In spatial planning, Lumajang Regency was determined to be a disaster-prone area including floods, tsunamis, and others. On the other hand, Lumajang Regency is also determined as a mining area. This shows the overlapping of land use plans. Land conflicts must be very vulnerable in the area like this.[3]

Conflict is sometimes associated with society reflecting the phenomenon of violence. Therefore, the conflict must be prevented or eliminated. This thought creates the concept of conflict prevention or conflict avoidance. Acts of violence such as fighting, vandalism, burning of property and killing to war are a bad phenomenon in the society, so it creates the concept of conflict prevention, where conflict must be prevented through various community or government policies. This concept is increasingly strengthened in Indonesia when seen from the fact that the conflicts which occur are often accompanied by acts of violence.

Another view which perceives that conflict is not a bad thing because conflict must be distinguished from acts of violence. "... conflict is a social phenomenon that is universal and inherent in people's lives, in social interaction between individuals and between individuals and groups ...". Prevention is carried out on acts of violence that usually accompany a conflict. Avoiding conflicts in the social dynamics of society is impossible. What can be done is how the conflict must be managed, controlled, and settled together wisely and peacefully. Therefore, it will not run to the violence, anarchy or destructive that cause disintegration or destroy the social relations in people's lives.[4]

Article 1 number 1 of Law Number 4 of 2009 concerning Mineral and Coal Mining, regulates the definition of mining that is: "a part or all activity stages in the framework of mineral and coal research, management, and exploitation and which includes general investigations, exploration, feasibility studies, construction, mining, processing and purification, transport, and sales, as well as post-mining activities".[5] This definition is a broad understanding because it covers a variety of mining activities that the scope can be carried out before mining process, when the mining process conducted, and after the mining process.[6]

The issue of authority is also a potential conflict between the Provincial Government and the Regency / City Government. Through the revocation of Law Number 32 of 2004 concerning Local Government and replaced by Law Number 23 of 2014 concerning Regional Government, the Regency / City Government got confuse to take steps. On the other hand, mining business also find it difficult to apply for a permit because there is no Government Regulation in Law Number 23 of 2014 concerning Local Government. In Law Number 23 of 2014 concerning Local Government has revoked the authority of the Regency/City Government to grant Mining Business Permits.[7]

\section{RESEARCH METHOD}

Researchers used empirical juridical research methods obtained through several techniques. Data collection techniques used by researchers in the form of observation, interviews, and literature studies. Researchers analyze the existence of disputes and identify the dispute resolution mechanisms that have been carried out and find the ideal dispute resolution strategy.

The research approach used is a sociological juridical approach. A sociological juridical approach is used to find out and discover how iron sand mining dispute resolution has been carried out at the research location including: How are the assumptions about mining 
dispute resolution that have occurred up to now; What are the consequences of resolving mining disputes that have occurred so far; What are the consequences of the treatment of disputing parties related to the resolution of mining disputes that have occurred so far; What are the implications of the implementation of mining dispute resolution that has been occurring for local governments, communities around the mine and mining businesses; What legal basis is used in resolving mining disputes that have occurred so far; and What is the ideal strategy for mining dispute resolution mechanisms. So that accurate data can be obtained.

\section{RESULTS AND DISCUSSION}

The conflict theory specifically used in this study is the conflict theory of Ralf Gustav Dahrendorf. In summary, the Dahrendorf conflict theory describes how authority is the source of conflict, how conflict is formed, and several conditions that influence it. Conflict situations are interesting to learn in order to gain lessons and values that can be useful for improving people's lives better in the future.[8]

Conflict cannot be separated from community activities including interaction between individuals, groups, and countries, as well as an interaction with environment. As Kornblurn emphasized, Novri cited, "Conflict is the most frequently occurring phenomenon because conflict is a part of human life that is social and political as well as being a driver in social and political dynamics and change."[9] Kornblurn's affirmation of society always moves towards this change with Dahrendorf when criticizing Talcott Parson's Structural Functionalism Theory which put forward the equilibrium.[10]

Dahrendorf developed this thesis of conflict theory based on the thought of Talcott Parson, a figure of structural functionalism. He corrected the theory of structural functionalism which formulated that society is always in a stable state. As quoted by Novri, Dahrendorf "rejects the utopia of functionalism which over emphasizes the consensus in social systems excessively. The face of society is not always in an integrated, harmonious, and mutually fulfilling condition, but there are other faces that show conflict and change."[9]

Quoting D. Lockwood's view, Dahrendorf explains: "Parsons's concept is heavily burdened by assumptions and categories related to the role of normative elements in social behavior, and especially with regard to the process by which the motives are socially structured. Apart from that, the so-called substratum of social behavior, especially conditions of interest that create social conflict and instability tends to be ignored as a general factor that determines the dynamics of society."[11]

The mining case in Lumajang Regency makes every community of Lumajang Regency subject to a process of change, namely the existence of conflict and conflict in every social system, this is done by the community element that plays a role in the birth of disintegration and change, so that Dahrendorf's main thesis on the difference in the distribution of authority has always been a factor determinant of systematic social conflict.

The definition of power formulated by Dahrendorf was the same as that formulated by Marx Weber namely as an individual's ability to impose his desires on others even though there are groups who oppose. Furthermore, Dahrendorf gave many explanations about authority in the context of union which was formed by force but not only because of coercion but also needed legitimacy as determining authority. "Power basically relates to social personality, whereas authority always relates to one's social position or role".[11] This distinction provides an affirmation of a position that will definitely provide officially legitimate power, whereas power can only apply when individuals have the capital or ability to control others, such as networking, 
power and authority are scarce resources that make groups competing with each other and fighting.

Authority becomes a legitimate relationship, without protests with authoritative sanctions, this is actually the actual function of the legal system to support the exercise of authority that has legitimacy. When examining the mining case in Lumajang Regency from the social context underlying the Dahrendorf conflict theory, this theory has an interest in the welfare of developing countries that are poor because of the development of capitalism.[12] In other words, conflict theory has a concern in helping developing countries rise from adversity as a result of capitalist systems in Western countries.

Seeing also from the substance that emphasizes authority as a source of conflict rather than to maintain integrity, this theory leads attention to groups within a country and the scope of modern society which does not have the authority to fight for their destiny. In contrast to the theory of functionalism favored by authoritarian government as explained by Ramlan Surbakti that "structural-functional theory is preferred by the ruling government, because this theory favors integrity, harmony, harmony and balance, and stability."[13]

The values, norms, politics, economics and beliefs systems greatly influence the choice of institutional forms and conflict resolution models in society. There are at least 2 different types of conflict resolution institutions, namely: (1) traditional conflict resolution institutions, which originate from the political and legal systems of the people and which traditionally operate (folk institutions); and (2) dispute settlement institutions built from State political and legal systems.[4]

Alternative Dispute Resolution outside the court has also been regulated in Law Number 30 of 1999 concerning Arbitration and Alternative Dispute Resolution.[14] In this regard, there have been several institutions that support Alternative Dispute Resolution methods, including Indonesian National Arbitration Board (Badan Arbitrase Nasional. Indonesia - "BANI") which focuses on the trade and Alternative Dispute Resolution in the settlement of construction service disputes regulated in Law Number 18 of 1999 jo Law Number 29 of 2000 jo Government Regulation Number 29 of 2000 with civil jurisdiction. Likewise, there are other Alternative Dispute Resolutions issues, such as issues on copyright and intellectual work, labor, business competition, consumers, environment and others.[15]

\section{CONCLUSIONS}

Based on the results of the analysis, alternative dispute resolution concerning mining in Lumajang Regency, there needs to be a consensus as the most important part in society's life. This is shown in the Dahrendorf conflict theory also explains the actions of conflict groups that are directed to change.

Empowerment groups need to be involved in conflict. In addition, it also explains latent interests, manifest interests, and ideal conditions that accelerate or slow down the conflict process.

It must be understood that in an effort to changes the structure of society, conflicts does not occur because of social classes, but differences in authority within groups. This is consistent with the state of society and government that has entered the phase of modern industrial society.

It is necessary to immediately issue a Government Regulation in implementing regulations from the provisions of Law Number 23 of 2014 concerning Local Government that in this context to prevent conflicts of authority between the Provincial Government and Regency / City Governments, specifically related to the procedures for granting Mining Business Permits. 


\section{REFERENCES}

[1] I. D. Qurbani, "Alternatif Penyelesaian Sengketa Pertambangan Pasir Besi (Iron Sand) di Provinsi Jawa Timur,” Malang, 2016.

[2] R. Syafaat and I. D. Qurbani, “Alternatif Penyelesaian Sengketa Pertambangan (Studi di Kabupaten Lumajang Provinsi Jawa Timur)," J. Mahkamah Konstitusi, vol. 10, no. 14, 2017.

[3] Badan Penanggulangan Bencana Daerah Lumajang, "Rencana Strategis (Revisi) 2015 2019," Lumajang: BPBD, 2015.

[4] I. N. Nurjaya, "Konflik dan Budaya Penyelesaian Konflik dalam Masyarakat:Perspektif Antropologi Hukum," in Pengelolaan Sumber Daya Alam dalam Perspektif Antropologi Hukum, Jakarta: Prestasi Pustaka Publisher, 2008.

[5] Law Number 4 of 2009 concerning Mineral and Coal Mining. .

[6] G. Supramono, Hukum Pertambangan Mineral dan Batubara Indonesia. Jakarta: Rineka Cipta, 2012.

[7] Law Number 23 of 2014 on Local Government. .

[8] İ. Güçlü, "Karl Marx and Ralf Dahrendorf: A Comparative Perspective on Class Formation and Conflict," Eskişehir Osmangazi Üniversitesi Iibf Derg., vol. 9, no. 2, 2014.

[9] N. Susan, Pengantar Sosiologi Konflik dan Isu-Isu Konflik Kontemporer. Jakarta: Kencana Prenada Media Group, 2010.

[10] J. H. Turner, The Srtucture of Sociological Theory. USA: The Dorsey Press, 1974.

[11] R. K. D. Susilo, 20 Tokoh Sosiologi Modern: Biografi Para Peletak Sosiologi Modern. Yogyakarta: Ar-Ruzz Media, 2008.

[12] J. Tittenbrun, "Ralph Dahrendorf's Conflict Theory of Social Differentiation and Elite Theory," Innov. Issues Approaches Soc. Sci., vol. 6, no. 3, 2013.

[13] B. Suyanto and M. K. Amal, Anatomi dan Perkembangan Teori Sosial. Yogyakarta: Aditya Media Publishing, 2010.

[14] Law Number 30 of 1999 on Arbitration and Alternative Dispute Resolution. .

[15] A. Alkostar, "Alternative Dispute Resolution Sebagai Salah satu Bentuk Mekanisme Pemecahan dan Penanganan Masalah dalam Proses Penegakan Hukum Polri." 